Seminário de Pesquisa

Programa de Pós-Graduação

Design FAU USP

\title{
0 papel do design como fator da inovação para um mundo tecnológico 4.0
}

\author{
Laercio Marques da Silva, Denise Dantas
}

\author{
design; inovação; tecnologia; indústria 4.0
}

O escopo a que se propõe esta pesquisa de dissertação de mestrado, ainda em estágio inicial de desenvolvimento, é refletir sobre como novas tecnologias, da chamada indústria 4.0 (KAGERMANN, 2013), impactam no processo criativo do design. Com a crescente, veloz e exponencial evolução da tecnologia, o design passa a ter papel central na identificação, sistematização e implementação de soluções e processos, que vão de encontro às reais e efetivas necessidades das pessoas (MANZINI, 2017). 0 que se pode depreender de um estudo qualitativo, que busque

\section{Curso}

Mestrado

\section{Linha de Pesquisa}

Design: Processos e Linguagens

\section{Laercio Marques da Silva}

Designer industrial e consultor

em inovação. Mestrando no curso de Pós-graduação em Design pela FAUUSP. Possui graduação em Design de Produto (Belas Artes) e MBA em Branding (Rio Branco - Brunel University), além de especialização em design e tecnologia digital (FAAP).

e-mail: laercio.marques@usp.br Lattes: http://lattes.cnpq. br/1339926392971734

Orcid: https://orcid.org/00000002-3002-2927

\section{Denise Dantas}

Docente na Universidade de São Paulo na graduação e pós-graduação em Design, coordenadora do LabDesign FAUUSP e colíder do grupo de pesquisa Design em Ação. Realiza pesquisas em Human Centred Design, Inovação social, Materiais para o design.

e-mail: dedantas@usp.br

Lattes: http://lattes.cnpq. br/7636937300587505

Orcid: https://orcid.org/00000003-4419-6394 sistematizar percepções informadas e abalizadas de reconhecidos especialistas, além de referências recentes extraídas da literatura especializada, acerca das potencialidades de desenvolvimento, para novos produtos e sistemas produto-serviço, na terceira década do século XXI? Objetiva-se levantar dados e tendências, analisar em profundidade e descrever as principais transformações projetuais para o campo do design, bem como discorrer sobre suas implicações práticas para o desenvolvimento de novos produtos em indústrias, escritórios e departamentos de desenvolvimento. Trata-se de um estudo de reconhecimento, com uma abordagem exploratória, do tipo qualitativa, que se fundamentará essencialmente em revisão da literatura especializada e publicações nas áreas de inovação, design, tecnologia e desenvolvimento industrial, além da coleta e tratamento de dados por meio de grupos focais e entrevistas em profundidade semiestruturadas conduzidas junto a especialistas selecionados (FLICK, 2009). Com a devida análise e sistematização dos dados obtidos, estima-se chegar a resultados relevantes para o campo do design, a respeito do impacto transformacional destas tecnologias em termos de novas gamas de produtos e serviços potencialmente viáveis. 


\title{
The role of design as a factor of innovation for a technological world $\mathbf{4 . 0}$
}

\author{
Laercio Marques da Silva, Denise Dantas
}

design; innovation; technology; industry 4.0

The scope of this master's dissertation research, which is still in the initial stage of development, is to reflect on how new technologies, of the so-called industry 4.0 (KAGERMANN, 2013), impact on the creative design process. With the growing, fast and exponential evolution of technology, design has a central role in the identification, systematisation and implementation of solutions and processes, which meet the real and effective needs of people (MANZINI, 2017). What can be inferred from a qualitative study, that seeks to systematise informed and empowered perceptions of recognised specialists, in addition to recent references extracted from the specialised literature, about the development potential, for new products and product-service systems in the third decade of the 21st century? The objective is to gather data and trends, analyse in depth and describe the main design changes in the field of design, as well as to discuss their practical implications for the development of new products in industries, design offices and development departments. This is a recognition study, with an exploratory approach, of a qualitative type, which will be based essentially on a review of the specialised literature and publications in the areas of innovation, design, technology and industrial development, in addition to the collection and treatment of data through focus groups and in-depth semi-structured interviews conducted with selected experts (FLICK, 2009). With due analysis and systematisation of the data obtained, it is estimated to arrive at results relevant to the field of design, regarding the transformational impact of these technologies in terms of new ranges of potentially viable products and services.

\section{Referências | References}

FLICK, U. 2009. Introdução à pesquisa qualitativa. Porto Alegre: Artmed. KAGERMANN, H.; WAHLSTER, W. \& HELBIG, J. (eds.) 2013. Securing the future of German manufacturing industry: Recommendations for implementing the strategic initiative INDUSTRIE 4.0. Final report of the Industrie 4.0 Working Group. <https://www.din.de/blob/76902/e8cac883f42bf28536e7e8165993f1fd/ recommendations-for-implementing-industry-4-0-data.pdf> 01/12/2020.

MANZINI, E. 2017. Design: Quando todos fazem design. Uma introdução ao design para a inovação social. São Leopoldo: Unisinos.

\section{Denise Dantas}

Lecturer for the under and post graduate Design programs at the University of São Paulo, coordinator of LabDesign FAUUSP and co-chair of the research group Design in Action. Active researcher in human centered design, social innovation and materials for design.

e-mail: dedantas@usp.br

Lattes: http://lattes.cnpq. br/7636937300587505

Orcid: https://orcid.org/00000003-4419-6394 